\title{
Topographic Map Analysis of Laramie Range Bedrock-Walled Canyon Complex and the Goshen Hole Escarpment-Surrounded Basin, Albany and Platte Counties, Southeast Wyoming, USA
}

\author{
Eric Clausen \\ Independent Researcher, Jenkintown, PA 19046, USA \\ Email: eric2clausen@gmail.com
}

How to cite this paper: Clausen, E. (2018) Topographic Map Analysis of Laramie Range Bedrock-Walled Canyon Complex and the Goshen Hole EscarpmentSurrounded Basin, Albany and Platte Counties, Southeast Wyoming, USA. Open Journal of Geology, 8, 33-55.

https://doi.org/10.4236/ojg.2018.81003

Received: December 7, 2017

Accepted: January 13, 2018

Published: January 16, 2018

Copyright $\odot 2018$ by author and Scientific Research Publishing Inc. This work is licensed under the Creative Commons Attribution-NonCommercial International License (CC BY-NC 4.0). http://creativecommons.org/licenses/by-nc/4.0/

\begin{abstract}
The Laramie River after flowing in a north direction through southeast Wyoming's Laramie Basin abruptly turns in an east direction to flow across the north-to-south oriented Laramie Range in a bedrock-walled canyon and eventually reaches the lower elevation Great Plains and southeast-oriented North Platte River. The North Laramie River, Bluegrass Creek, and North Sybille/Sybille Creek also flow from the Laramie Basin in separate bedrockwalled valleys into the Laramie Range before eventually joining the Laramie River. Bedrock-walled through valleys link the various Laramie Range stream and river crossing valleys and detailed topographic maps were used to determine how this anastomosing bedrock-walled canyon complex and the large escarpment-surrounded Goshen Hole basin (located just to the east of the anastomosing canyon complex) originated. Map evidence shows multiple streams of water must have diverged in the Laramie Basin from the northoriented Laramie River to enter the Laramie Range before converging in or east of the Laramie Range and also shows how present day through valleys enabled diverging and converging streams of water to cross the Laramie Range. The anastomosing bedrock-walled valley complex studied here extends from north of the North Laramie River valley to south of the North Sybille/ Sybille Creek valley. Large volumes of water flowing from the Laramie Basin to the Great Plains are interpreted to have eroded the anastomosing canyon complex and the "downstream" Goshen Hole escarpment-surrounded basin. Headward erosion of the north-oriented Sybille and Chugwater Creek valleys across large sheets of east-oriented water are interpreted to have left the Go-
\end{abstract}


shen Hole escarpment-surrounded basin as a large abandoned headcut. A water source was not determined, although a continental ice sheet that deeply eroded and warped the North American continent is considered to be a possible source.

\section{Keywords}

Anastomosing Channel Complex, Deep Erosion by Continental Ice Sheets, Diverging and Converging Valleys, Great Plains, Laramie Basin, Laramie River, North Laramie River, Rocky Mountains, Sybille Creek

\section{Introduction}

J Harlan Bretz was one of the first to recognize the significance of anastomosing bedrock-walled valley complexes. In 1927 [1] when describing the Channeled Scablands of Washington State (USA) he stated, "Canyons in the scablands are multiple and anastomosing, amazingly so in labyrinthine fashion about bare rock knobs and buttes unlike any other land surface on the earth. Certainly but few of these canyons are inherited from the older [drainage] pattern." Bretz used the anastomosing canyons as one piece of evidence that an immense flood [later determined to be caused by the catastrophic failure of an ice dam holding back Glacial Lake Missoula] had crossed the region. According to Baker [2], who subsequently studied the region, "Anastomosis occurs in the Channeled Scabland because pre-flood valleys did not have the capacity to convey the Missoula Flood discharges without spilling over pre-flood divides into adjacent valleys. This crossing of divides produces the effect of channels dividing and rejoining" even though the channels are deeply eroded into the bedrock.

Following acceptance of Bretz's catastrophic flood hypothesis diverging and converging bedrock-walled valley complexes have contributed to discovery of several other significant catastrophic flood events. For example Kehew [3] proposed rapid drainage from Glacial Lake Regina (in Saskatchewan, Canada) overwhelmed existing drainage systems and carved an anastomosing complex of diverging and converging channels in glacial sediments and the easily eroded underlying north central North Dakota bedrock. Most catastrophic flood events identified by the presence of anastomosing complexes of bedrock-walled valleys are also located in or near glaciated regions and the responsible flood events are almost always associated with the rapid release of water from large glacially dammed lakes. However, anastomosing complexes of diverging and converging bedrock-walled valleys also exist far from known ice sheet boundaries and in regions far from any recognized glacially dammed lakes. One such example is the anastomosing complex of bedrock-walled valleys that crosses southeast Wyoming's high altitude Laramie Range, which this paper describes and analyzes.

Figure 1 uses a modified map from the United States Geological Survey (USGS) National Map website [4] to illustrate the Laramie Range location in 


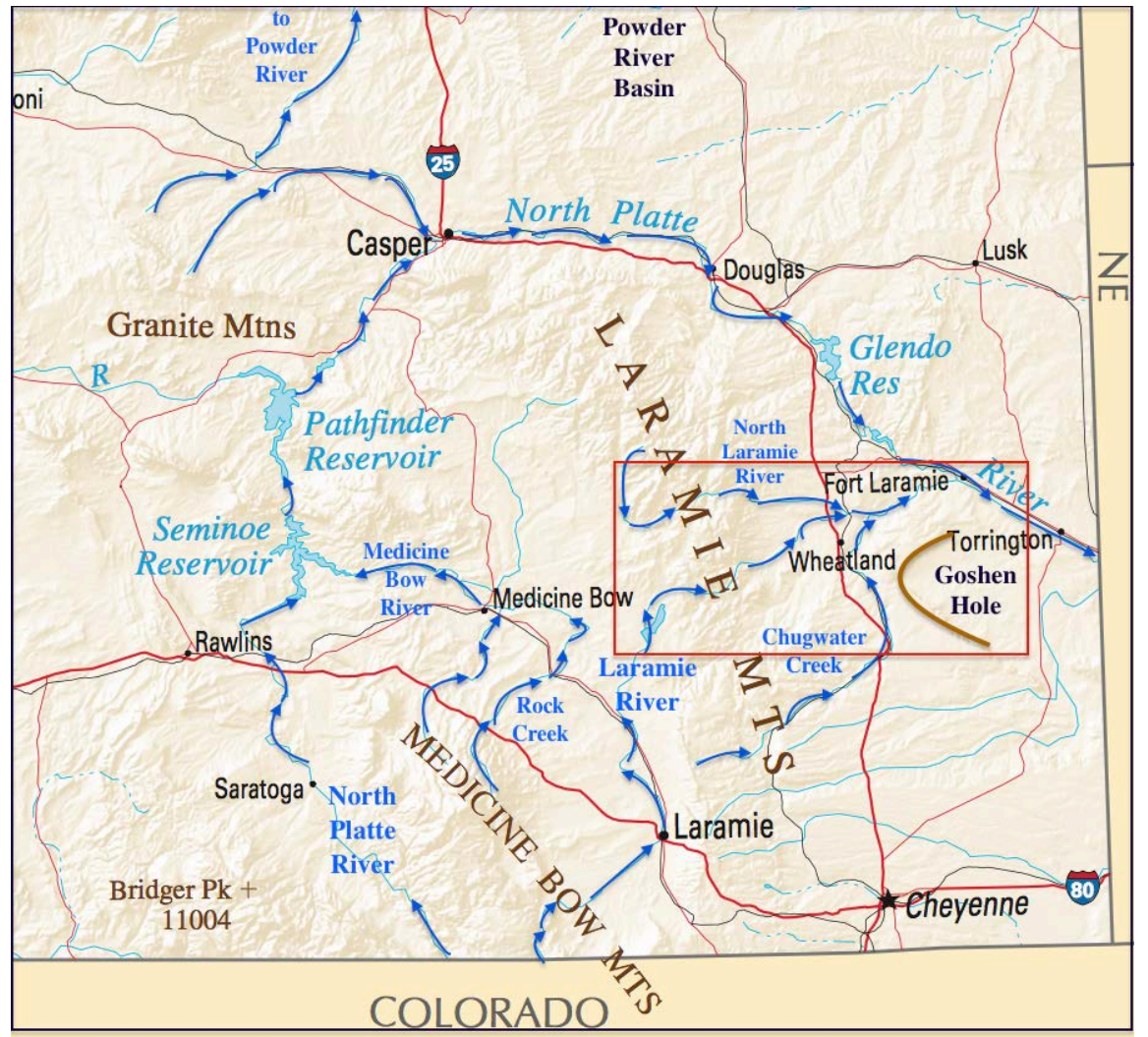

Figure 1. Modified map of southeast Wyoming from the United States Geological Survey (USGS) National Map website showing study area's location (red rectangle). Blue arrows show flow directions on major drainage routes discussed in the text. The Laramie Basin is located between the Laramie Mountains and the Medicine Bow Mountains. The letters NE stand for Nebraska-the state to the east of southeast Wyoming.

southeast Wyoming. The Laramie River begins in a northern Colorado mountain area (south of Figure 1) and flows in a north direction into the Laramie Basin (located between the Laramie Mountains and Medicine Bow Mountains) where it turns in an east and then northeast direction to cross the Laramie Range and to eventually reach the Great Plains where it joins the southeast oriented North Platte River. The North Platte River also begins in the same Colorado mountain area and its headwaters are linked by a deep through valley (south of Figure 1) with Laramie River headwaters and it then flows in a northwest direction into the Figure 1 southwest corner. As seen in Figure 1 the North Platte River flows around the Laramie Range northwest end before turning in a southeast direction. The Medicine Bow River is a North Platte River tributary originating in the Medicine Bow Mountains and drains the Laramie Basin areas to the west and north of the Laramie River drainage basin. The Goshen Hole escarpment-surrounded basin is located east of the Laramie Range and of the Laramie Range. A brown line has been added to emphasize the Goshen Hole escarpment-surrounded basin west end.

The north-to south oriented Laramie Mountains seen in Figure 1 separate southeast Wyoming's high altitude Laramie Basin (west) from the lower altitude 
Great Plains (east) and its north end curves in a northwest direction to the Casper area so it is also located between the Laramie Basin (south) and the Powder River Basin (north). The Laramie Range is often considered a northward extension of the Colorado Front Range and serves as Wyoming's frontal range. Thornbury [5] describes the Laramie Range as "a broad asymmetrical anticlinal structure with a steeper east than west limb, [and] with a Precambrian granitic core." He adds, "By the end of Pliocene time Tertiary sediments extended well onto the area of Precambrian rocks, or largely covered them. Pleistocene uplift started the stripping of Tertiary sediments that has continued to the present."

Thornbury regards the Laramie River as one of a "large number of [Rocky Mountain] streams that flow directly across mountain uplifts through deep gorges" formed by either antecedence or superposition. His map illustrating Rocky Mountain canyon locations shows the Laramie River crossing the Laramie Range but does not show any other streams crossing the Laramie Range. Yet, north of the Laramie River canyon the North Laramie River flows in a separate valley across the Laramie Range and south of where the Laramie River crosses the Laramie Range North Sybille/Sybille Creek (not shown in Figure 1) crosses the Laramie Range in its own canyon and is joined by streams and through valleys that originate in the Laramie Basin and then flow across much of the western Laramie Range. Linking canyons that cross the Laramie Range is a network of diverging and converging through valleys suggesting a large east-oriented anastomosing complex of bedrock-walled stream or river channels eroded the entire canyon complex.

The multiple Laramie Range river and stream crossings within this paper's study region occur where Laramie Range crest elevations are lower than elevations found to the north and south. Laramie Range regions to the north contain high peaks standing above deep through valleys that link streams flowing in opposite directions off the Laramie Range core area. Lowest Laramie Range crest elevations are found between the Laramie River and North Sybille/Sybille Creek where the Laramie Range is in places not much more than a low ridge and an intensely eroded east-facing escarpment separating the high elevation Laramie Basin from the lower elevation Great Plains. The Laramie Range core bedrock in the most intensely eroded region is an intruded Laramie anorthosite complex [6] [7], which is different from the granite core found to the south and the Precambrian rock core found to the north. The Laramie anorthosite complex may be easier to erode than the Laramie Range bedrock core to the south and north, although bedrock differences do not account for the multiple Laramie Range stream crossings.

\section{Previous Work}

Mears [8] attributed Laramie Basin excavation that he thought had occurred since Pliocene time to rejuvenated streams and eolian deflation. While not addressing the diverging and converging bedrock-walled valleys he addressed the 
three streams flowing across the Laramie Range as follows: "Three parallel canyons cross the northern part of the Laramie Mountains, between the Laramie Basin and the Great Plains. The Laramie River flows through the middle gorge. The canyons to the north and south are currently occupied by the North Laramie River and Sybille Creek, which head in the Laramie Mountains, flow westward into the basin, turn along the basin margin, and then flow eastward through their respective gorges to join the Laramie River in the Great Plains." He also mentions how "on the west side of the Laramie Basin, Rock Creek emerges from the Medicine Bow Mountains and flows northeastward toward the gorges, but turns abruptly in a northwest direction to join the west-flowing Medicine Bow River. Unraveling this drainage history will require careful mapping of the distribution of alluvial gravel deposits from distinctive bedrock types in the Medicine Bow and Laramie Mountains." Unfortunately Mears did not unravel the Laramie Basin and Laramie Range drainage history and successive investigators have yet to do so.

More recent studies of Rocky Mountain and western Great Plains stream incision usually fail to mention canyons now cutting across various Rocky Mountain ranges such as the Laramie River system of canyons this paper discusses or the drainage history problems such the one raised by Mears. One such study [9] analyzed post-depositional tilt of the Ogallala Group (Miocene through early Pliocene in age) on the Cheyenne Tablelands, which are adjacent to and east of the Laramie Range and located just to the south of the region this paper describes. That study sought to determine how climate and tectonics affected post-depositional slope change. The study found "tilting of the Cheyenne Tablelands is most consistent with broad-wavelength tectonic uplift centered under the Rocky Mountains initiated during Ogallala deposition and continuing since deposition ceased." However the paper does not mention the diverging and converging pattern of through valleys discussed here, or similar anastomosing valley patterns found throughout the Cheyenne Tablelands area, nor does it mention the Goshen Hole escarpment-surrounded basin, which is located just to the north of the Cheyenne Tablelands.

Another study involving some of the same authors [10] reconstructed a datum surface from which Rocky Mountain regional incision could be measured again for the purpose of evaluating late Cenozoic tectonic and climatic influences. In that study, which encompassed a large Rocky Mountain region, the authors "suggest that post-Laramide basin filling resulted from slow subsidence during Oligocene to Miocene time [and that] incision into this basin fill surface began in late Miocene time and continues today." The authors attribute much of the present day Rocky Mountain relief to tectonic factors with climatic factors having a less important role. The study, while trying to determine how today's Rocky Mountain region relief developed, does not address how modern day Rocky Mountain drainage systems originated and evolved nor does it address how and why some Rocky Mountain rivers and streams, including the Laramie 
River and several of its tributaries, were able cut canyons across various Rocky Mountain ranges.

Unlike the diverging and converging Laramie Range canyons the escarpment-surrounded Goshen Hole basin has received considerable attention. Because no obvious east oriented drainage route now leads to the escarpment-surrounded basin many researchers have attributed Goshen Hole escarpment erosion to spring sapping and seepage weathering in siltstones underlying a more erosion resistant cap rock. For example Adams [11] states "the principal cause of the escarpment being best defined at the western border of Goshen Hole is the fact that practically no streams enter the lowland from that side. Upon examining the general map it will be seen that the drainage, which flows eastward from the Laramie Mountains north of Bear Creek is diverted into the Laramie River by Chugwater Creek, which has a northerly course west of Goshen Hole. The Goshen Hole escarpment has accordingly not been broken by streams, but has retreated as the result of the sapping at its base by the headwaters of the minor drainage." More recently Higgins [12] citing work by Osterkamp provided evidence supporting this escarpment retreat interpretation including the lack of external drainage from the surrounding upland surface, the presence of springs and seeps along the escarpment base, and the impossibility of undercutting by local streams in the Goshen Hole lowland.

While Goshen Hole escarpment retreat is frequently attributed to spring sapping and seepage weathering occasional workers have suggested alternate interpretations. For example Rapp et al. [13] described Goshen Hole erosion as follows: "The formation of Goshen Hole proper was generally similar... to formation of the valley of the North Platte River. As the river valley was cut below the Oligocene-Miocene (Brule-Arikaree) contact, several tributary streams whose courses were through the area now occupied by Goshen Hole proper also cut down below the contact. Goshen Hole began to form with the retreat of the escarpment along the contact. At this time Chugwater Creek was working headward toward the south from the Laramie River and intercepted the headwaters of the eastward-flowing streams that entered Goshen Hole."

While the Laramie River, North Laramie River, and North Sybille/Sybille Creek valleys now crossing the Laramie Range have puzzled previous investigators and there has been debate about the escarpment-surrounded Goshen Hole basin origin previous investigators have been reluctant to link the two different landforms or even to discuss their origins. As a result these features have not been addressed as a linked system and few if any previous researchers have recognized (in a publication) the anastomosing bedrock-walled canyon complex. During the author's much larger Missouri River drainage basin landform origins research project the anastomosing bedrock-walled valleys now crossing the Laramie Range and the Goshen Hole escarpment-surrounded basin were identified as landform features needing to be understood before the much larger Missouri River drainage basin origin could be properly explained. This paper is one of a 
series of papers aimed at describing and interpreting such evidence in ways that will lead to an understanding of how the much larger Missouri River drainage basin originated and evolved.

\section{Research Method}

The multi-year Missouri River drainage basin landform origins research project consisted of systematically studying detailed United States Geologic Survey (USGS) topographic maps of the entire Missouri River drainage basin and adjacent drainage basins to determine how major drainage divides within and surrounding the large and complex Missouri River drainage basin originated. Drainage divide origins were determined by using divide crossings (through valleys, wind gaps, etc.) as evidence of previous drainage routes and then using barbed tributaries, elbows of capture, asymmetric drainage divides, abandoned headcuts, and similar evidence to determine how many thousands of capture events altered earlier drainage routes so as to produce the present day Missouri River drainage basin drainage routes. Approximately 550 unpublished project essays (or research notes) can be found in blog format at the geomorphologyresearch.com website and related papers that have been published to date are included in this paper's citations.

The larger project found Missouri River drainage basin landform origins are best explained in the context of having been eroded during massive melt water floods emanating from a large North American ice sheet. That large ice sheet deeply eroded the underlying bedrock and caused significant warping of the continental crust in adjacent and other regions so as to create and occupy a deep "hole"-space that was subsequently opened up as the ice sheet melted. The ice sheet related crustal warping appears to have raised many North American mountain ranges and plateau areas as massive melt water floods moved across them. These finding are fundamentally different from most commonly accepted geologic and glacial history interpretations and require a major reinterpretation of North American late Cenozoic geologic and glacial history to be fully understood. Many landforms critical to understanding the Missouri River drainage basin origin have never been formally described, mush less interpreted, or if interpretations exist those interpretations are frequently controversial and rarely contribute to an understanding of the Missouri River drainage basin origin. Papers such as this one are being written to identify key landforms important to understanding the Missouri River drainage basin origin and to provide interpretations that will help future investigators develop an understanding how the Missouri River drainage basin originated and evolved.

The study described here focused on the Laramie Range area where streams flow across it and used detailed topographic maps obtained from the United States Geological Survey (USGS) National Map website [14] to document how valleys now crossing the Laramie Range form an anastomosing complex of diverging and converging bedrock-walled valleys used today by multiple east-oriented 
streams. In addition to describing each Laramie Range stream crossing valley the study also investigated each valley separately to determine how it is linked both upstream and downstream with the other Laramie Range stream crossing valleys. Approximate depths of stream crossing and other through valleys where they enter the Laramie Range were determined and compared with Laramie Basin linkages between the stream crossing valleys while approximate drainage divide elevations on floors of Laramie Range through valleys (that link the various stream crossing valleys) were determined and compared with their respective through valley depths. The large escarpment-surrounded Goshen Hole basin is located immediately to the east of the diverging and converging through valley complex, which suggests a relationship between the two features. The similarity between the Goshen Hole escarpment-surrounded basin and several South and North Dakota escarpment-surrounded basins was noted and used to suggest that large and prolonged east-oriented floods eroded both the Goshen Hole basin and the upstream diverging and converging bedrock-walled valley complex. The studied topographic map evidence was not adequate to determine a water source, although large and prolonged floods of continental ice sheet melt water flowing across an emerging Rocky Mountain region are considered a likely source for the required large volumes of water.

\section{Results}

\subsection{North Laramie River Bedrock-Walled Valley}

Today the North Laramie River is the northernmost of the streams crossing the Laramie Range. Figure 2 is a modified map from the USGS National Map website showing how the North Laramie River flows in a south direction from the

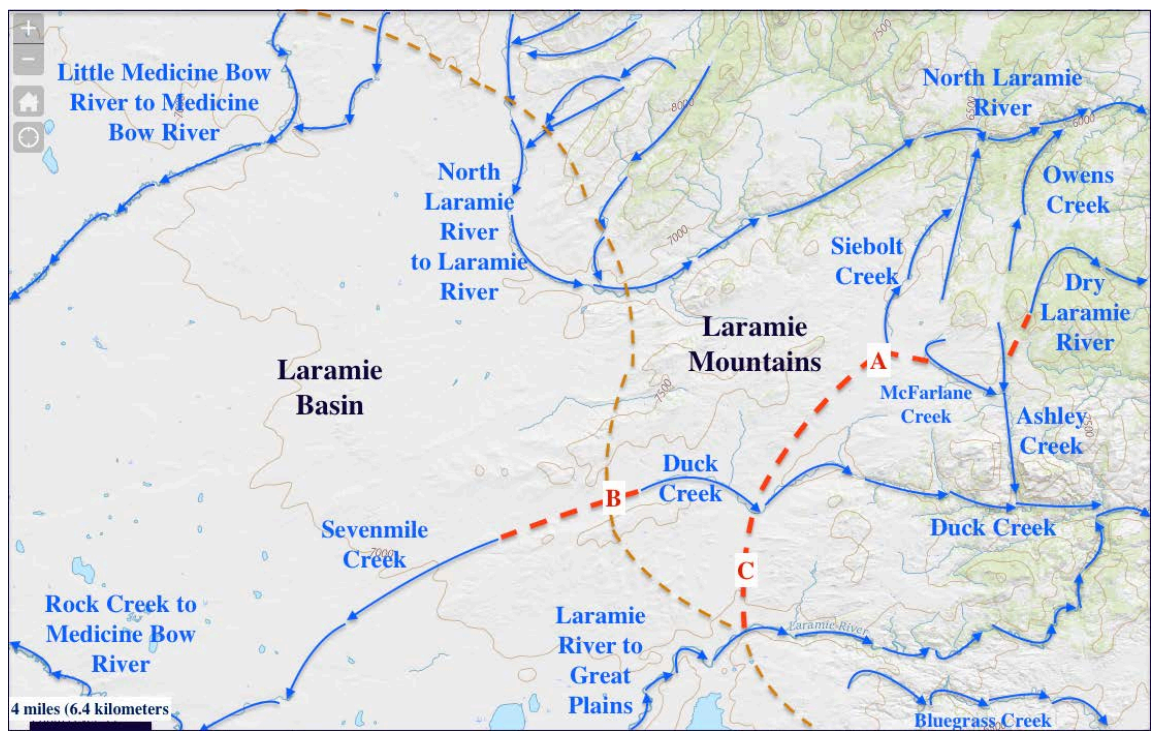

Figure 2. Modified map from USGS National Map website showing the North Laramie River-Laramie River relationship, Duck Creek, and west-oriented Medicine Bow River tributaries. The brown line shown the approximate Laramie Basin-Laramie Mountains boundary and the red dashed lines and red letters identify major through valleys. 
Laramie Mountains (north of Figure 2) into the Laramie Basin northeast corner where it crosses the 7000-foot (2134 meter) contour line and then turns abruptly in a northeast direction to enter a 400 -foot (122 meter) deep or deeper canyon through which it flows across the Laramie Range. West of the south-oriented North Laramie River headwaters are south-oriented Little Medicine Bow River headwaters, which once in the Laramie Basin turn in a southwest direction to join the west-oriented Medicine Bow River. The lowest point on the North Laramie River-Little Medicine Bow River drainage divide has an elevation of between 7140 and 7160 feet (2176 and 2182 meters) or approximately 150 feet (46 meters) higher than the nearby North Laramie River, which raises the question, "why does the North Laramie River turn in an east-northeast direction to enter a 400-foot (122 meter) deep or deeper canyon to cross the Laramie Range when it could have flowed in a west direction across much easier to erode Laramie Basin floor bedrock and a much lower drainage divide to reach the west-oriented Medicine Bow River?"

Note in Figure 2 how southwest-oriented tributaries join the south-oriented North Laramie River headwaters and suggest headward erosion of that south-oriented valley captured southwest-oriented streams and perhaps the present day northeast-oriented North Laramie River segment itself originated as a southwest-oriented stream and subsequently changed its flow direction. Supporting such an interpretation Blackstone [15] described rounded boulders in the Laramie Basin northeast corner (and in the North Laramie River headwaters area) "in a fanlike arrangement opposite the mouths of southwestward flowing drainages... The size of the boulders decreases rather regularly away from the mountain front, but no well-exposed bedded deposits have been observed. The age of these boulders has been variously interpreted as Paleocene, Eocene, Oligocene, and Pleistocene." He suggests the boulders may have been deposited during a period of high Pleistocene precipitation, although Mears argues periglacial wedges in the non-glaciated Laramie Mountains suggest Pleistocene precipitation was no greater than at present. Whatever their age the boulders and the southwest-oriented North Laramie River tributaries suggest large volumes of southwest oriented water probably once flowed from or across the Laramie Range to enter what is today the Medicine Bow River drainage basin and were subsequently captured when southwest-oriented water in what is today the northeast-oriented North Laramie River valley reversed its flow direction and then eroded headward to capture what are today multiple southwest-oriented North Laramie River tributaries.

Location A in Figure 2 is on the floor of a northeast-oriented through valley (shown by a dashed red line) that links the Duck Creek valley with the North Laramie River valley. Duck Creek as seen in Figure 2 is an east-oriented Laramie River tributary (it is discussed in detail in a separate text section). Today Siebolt and Sturgeon Creeks drain the through valley's north end to the North Laramie River and Wallace and Mertz Draws drain the through valley's south end to Duck Creek. The drainage divide between the north- and south-oriented drai- 
nages on the through valley floor is known as Davidson Flats with the drainage divide having an elevation of between 7060 and 7080 feet (2152 and 2158 meters). Elevations on Brandel Mountain, located to the west of Davidson Flats exceed 7760 feet (2365 meters) while elevations on an unnamed mountain to the east of Davidson Flats rise to 7969 feet (2429 meters) suggesting the through valley is 680 feet (207 meters) deep. Love et al. [16] mapped White River Formation of Oligocene age on the through valley floor (south of the Siebolt Creek headwaters). The through valley also extends in a south-southwest direction from the Duck Creek valley to the Laramie River (that segment is discussed in the following Duck Creek and Laramie River text sections) and provides evidence that water once flowed between the Laramie River and North Laramie River valleys. Today Duck Creek crosses the 6960-foot 2121 meter) contour line near where Mertz Draw enters it and the North Laramie River crosses the 6160-foot (1878 meter) contour line near where Sturgeon Creek enters it suggesting the drainage divide area has been raised at least 100 feet (30.5 meters) since water ceased to flow across it. To the east of Figure 2 the North Laramie River after descending to the Great Plains joins the Laramie River at an elevation of less than 4500 feet (1372 meters).

\subsection{Duck Creek Bedrock-Walled Valley}

The east oriented Duck Creek valley seen in Figure 2 is located between the North Laramie River and the Laramie River. Duck Creek originates near location B at an elevation of between 7380 - 7400 feet (2245 - 2250 meters) and flows in roughly an east direction into the Laramie Range where Duck Creek joins the Laramie River to complete its Laramie Range crossing. Duck Creek does not originate in the Laramie Basin, but instead originates in a through valley a short distance east of the Laramie Basin. The through valley links the northeast oriented Duck Creek headwaters with headwaters of southwest-oriented Sevenmile Creek with water eventually reaching the Medicine Bow River. Elevations both north and south of location B rise to more than 7600 feet (2316 meters) and suggest the bedrock-walled through valley now linking the opposing Duck and Sevenmile Creek valleys is more than 200 feet (61 meters) deep.

Southwest-oriented water moving across the Laramie Range into the present day Laramie Basin, where water at that time may have been flowing in a south direction, probably initiated the through valley that now links Duck and Sevenmile Creeks. Headward erosion of the deeper south-southwest oriented through valley now linking the Laramie River, Duck Creek, and North Laramie River valleys (identified by locations $\mathrm{A}$ and $\mathrm{C}$ in Figure 2) dismembered the southwest-oriented flow and created the present day drainage divide at location $\mathrm{B}$. That dismemberment was caused by headward erosion of the southeast-oriented Duck Creek valley segment north of the letter $\mathrm{C}$ and caused a reversal of flow to create the northeast-southeast-oriented Duck Creek headwaters segment with the reversed flow then turning in south-southwest direction to move in the 
through valley identified by the letter $\mathrm{C}$ to the present day Laramie River valley and probably to enter Laramie Basin.

Duck Creek after entering the south-southwest oriented through valley (identified by letters $\mathrm{A}$ and C) turns today in a northeast direction to flow along the through valley floor before turning in an east-southeast direction to flow into the Laramie Range heart. The narrow and bedrock-walled Duck Creek canyon is in places almost 700 feet (213 meters) deep and eventually joins the Laramie River. Less obvious and higher elevation through valleys link the east-southeast oriented Duck Creek valley with both the through valley identified by the letter A and with the North Laramie River valley suggesting through valleys discussed in this paper may have captured diverging and converging streams of water that had been eroding what are today remnants of a higher elevation and more difficult to decipher bedrock-walled valley complex. For example east of the through valley identified by the letter $\mathrm{A}$ is a south-to-north oriented through valley drained today by south-oriented Ashley Creek to east-southeast oriented Duck Creek and by north- and northeast-oriented Owens Creek to the North Laramie River. The Owens-Ashley Creek drainage divide elevation on that through valley floor is 7252 feet (2210 meters) while Britannia Mountain immediately to the east rises to more than 7930 feet (2417 meters) and an unnamed mountain immediately to the west rises to 7969 feet (2429 meters) suggesting the through valley is almost 700 feet (213 meters) deep.

The through valley identified by the letter A is also linked by still other through valleys with the Owens-Ashley Creek through valley, the deepest of which originates at Davidson Flats (which is also on the previously described North Laramie River-Duck Creek through valley drainage divide) at an elevation of between 7040 and 7060 feet (2146 and 2152 meters) and is drained in a southeast direction by McFarlane Creek to south-oriented Ashley Creek. North of McFarlane Creek multiple and somewhat less obvious and higher elevation southwest-oriented through valleys link the Owens Creek and Sturgeon Creek valleys (both of which now drain to the North Laramie River). East of the Owens Creek-Ashley Creek through valley are other interesting through valleys such as a 300-foot (91 meter) deep through valley linking the north-northeast oriented Dry Laramie River headwaters valley with a southwest-oriented Ashley Creek tributary valley (with a drainage divide floor elevation greater than 7400 feet or 2256 meters). The Dry Laramie River-Ashley Creek through valley suggests headward erosion of the Ashley Creek valley captured southwest-oriented water that was subsequently beheaded and reversed by headward erosion of the deeper southeast oriented Dry Laramie River valley (which today joins the Laramie River at an elevation of less than 4600 feet or 1402 meters).

These and other similar examples suggest the east-oriented Duck Creek valley eroded headward across multiple streams of southwest-oriented water and diverted that water to the east-oriented Laramie River valley and that subsequently other east-oriented Laramie River tributary valleys, including the Dry Laramie River valley, eroded headward into the region to capture south-and south- 
west-oriented water moving to the newly eroded Duck Creek valley with headward erosion of the deeper North Laramie River valley finally capturing all of the south- and southwest-oriented flow. If correctly interpreted headward erosion of the deeper east-southeast oriented Duck Creek valley segment captured southsouthwest oriented water moving in the through valley identified by the letters $\mathrm{A}$ and $\mathrm{C}$ and diverted that water eastward toward the Great Plains. Such a capture probably occurred while water in the Laramie Basin was still moving in a south direction and would have beheaded flow moving in the through valley identified by the letter $\mathrm{C}$ and reversed flow on the northeast end of that valley so as to create what is today the northeast oriented Duck Creek segment now on that through valley floor. The capture also enabled the east-southeast oriented Duck Creek valley to capture the previously described and reversed northeast and southeast oriented Duck Creek headwaters segment.

\subsection{Laramie River Bedrock-Walled Valley}

Today the Laramie River (seen in Figure 1 and Figure 3 ) is the only stream draining any significant Laramie Basin area that also flows across the Laramie Range. However, while the north oriented Laramie River drains the southern Laramie Basin the north-and west-oriented Medicine Bow River drains much of the northern Laramie Basin. The Laramie River has an elevation of about 6900 feet (2100 meters) where it enters the Laramie Range and the highest Laramie Range crest elevations between Duck Creek and the Laramie River are about 7850 feet (or slightly less than 2400 meters). Interestingly the drainage divide between the Laramie River and Medicine Bow River (Rock Creek) to the west of where the Laramie River turns to leave the Laramie Basin and to enter the Laramie Range has an elevation of less than 7000 feet (2134 meters).

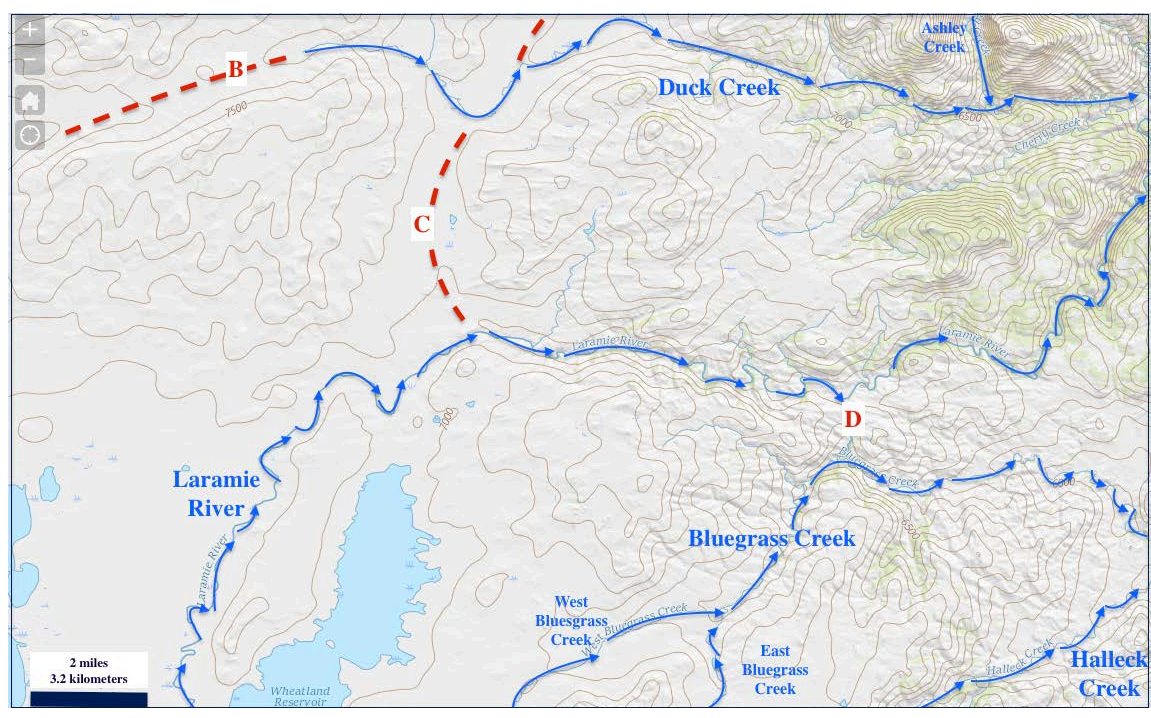

Figure 3. Modified topographic map from the USGS National Map website showing where the Laramie River enters the Laramie Range. Arrows emphasize drainage routes discussed in the text and show flow directions. The contour interval is 100 feet $(30.5$ meters). 
The letter D in Figure 3 identifies a man made tunnel used to move irrigation water from the Laramie River to the lower elevation Bluegrass Creek valley (Figure 4 provides a detailed topographic map of the location $\mathrm{D}$ area). Today both Bluegrass Creek and the Laramie River flow completely across the Laramie Range with Bluegrass Creek originating in the Laramie Basin adjacent to the Laramie River and then flowing to Sybille Creek, which joins the Laramie River once on the Great Plains. The large lake in Figure 4 is one of several irrigation project water storage reservoirs. The letters $\mathrm{B}$ and $\mathrm{C}$ identify previously discussed through valleys that are also shown in Figure 2.

As seen in Figure 1 and Figure 3 the Laramie River flows in a north direction along the Laramie Range west flank before turning abruptly in an east direction to enter the Laramie Range even though the previously discussed north-northeast oriented through valley (at the letter "C") continues to the Duck Creek and North Laramie River valleys. Also notice how the east oriented Laramie River once it is in the heart of Laramie Range turns to join the east oriented Duck Creek valley (better seen in Figure 2) before resuming its east oriented direction to reach the Great Plains. Before being captured by headward erosion of the east-oriented Laramie River valley (and Duck Creek valley) water probably flowed in a south-southwest direction in the through valley at the letter $\mathrm{C}$ to enter the Laramie Basin while the east-oriented Duck Creek and Laramie River valleys were still eroding headward into the Laramie Range. At that time water must also have flowed in a south direction once in the Laramie Basin and continued southward into Colorado. Today the lowest drainage divides at the Laramie Basin south end are at least 1000 feet (305 meters) higher than where the Laramie River turns enter the Laramie Range, which means Laramie Basin drainage has since been reversed. Crustal warping probably raised the Laramie Basin

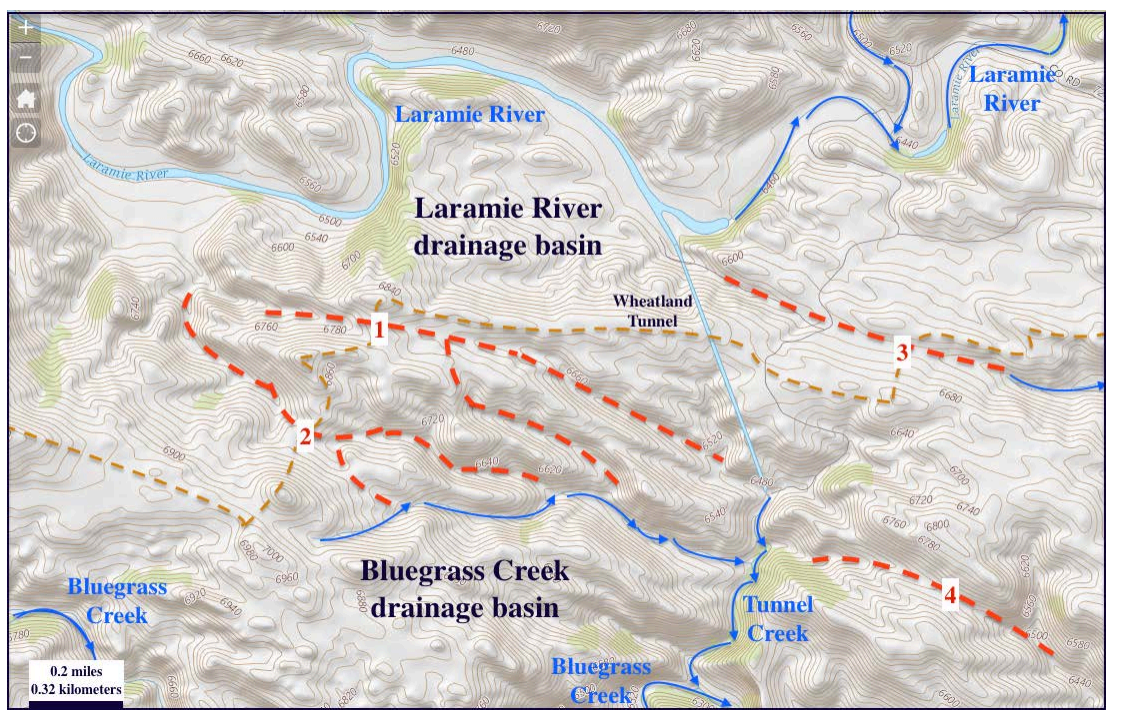

Figure 4. Modified topographic map (contour interval 20 feet or 6 meters) taken from the USGS National Map website. Blue arrows emphasize drainage routes and flow directions. The dashed red lines and red numbers show locations of through valleys discussed in the text and the dashed brown line shows the Laramie River-Bluegrass Creek drainage divide. 
south end, although headward erosion of the east-oriented Laramie River canyon (across the Laramie Range) and into the Laramie Basin may have triggered the capture and the resulting Laramie Basin drainage reversal.

Figure 4 provides a detailed map of the location D area (seen in Figure 3 ) and shows where the Wheatland Tunnel diverts Laramie River water to the Bluegrass Creek valley [17]. The Laramie River is at the top while Bluegrass Creek is at the bottom. A low dam diverts Laramie River water into the Wheatland Tunnel and then to south oriented Tunnel Creek, which flows to Bluegrass Creek. Several northwest-to-southeast oriented through valleys link the Laramie River valley with Bluegrass Creek tributaries. The Laramie River crosses the 6500-foot (1981-meter) contour line near the Figure 4 northwest corner and Bluegrass Creek crosses the 6300-foot (1920-meter) contour line near where Tunnel Creek joins it. The drainage divide on through valley 1 has a floor elevation of between 6820 and 6840 feet (2079 and 2085 meters), on through valley 2 a floor elevation of between 6780 and 6800 feet (2067 and 2073 meters), and on through valley 3 a floor elevation of between 6600 and 6620 feet (2012 and 2018 meters). Remember the Laramie River crosses the 6900-foot (2103-meter) contour line as it enters the Laramie Range so these drainage divides are all lower than the Laramie Basin floor. These through valleys suggest diverging and converging streams of water crossed the Laramie River-Bluegrass Creek drainage divide prior to headward erosion of the deeper east-oriented Laramie River valley. Through valley 4 crosses the divide between Tunnel Creek and Bluegrass Creek at an elevation of between 6640 and 6660 feet (2024 and 2030 meters).

Note how the entire Laramie River-Bluegrass Creek drainage divide area has been streamlined in a northwest to southeast direction suggesting intense erosion by large volumes of southeast-oriented water moving from the upstream Laramie River valley to the downstream Bluegrass Creek valley. This evidence suggests the Laramie River valley (in this region) eroded headward across massive southeast-oriented volumes of water moving to what at that time was the deeper Bluegrass Creek valley. The south-oriented Tunnel Creek valley eroded headward in a north direction as it captured the southeast-oriented flow and diverted the water to the deep Bluegrass Creek valley. Subsequently Laramie River valley headward erosion beheaded southeast-oriented flow routes to the Tunnel Creek valley (now through valleys 1 and 2) to create drainage routes that exist today. Evidence seen in Figure 4 suggests the Laramie River valley eroded headward across and captured large volumes of southeast-oriented water that once flowed to the Bluegrass Creek valley, which today leads to the northeast-oriented Sybille Creek valley and eventually to the Great Plains and the Laramie River valley.

\subsection{Bluegrass Creek Bedrock-Walled Valley}

Figure 5 provides a map of the Bluegrass Creek headwaters area and illustrates diverging and converging valleys originating adjacent to the north oriented Laramie River that also provide links to either the Bluegrass Creek or Sybille Creek 


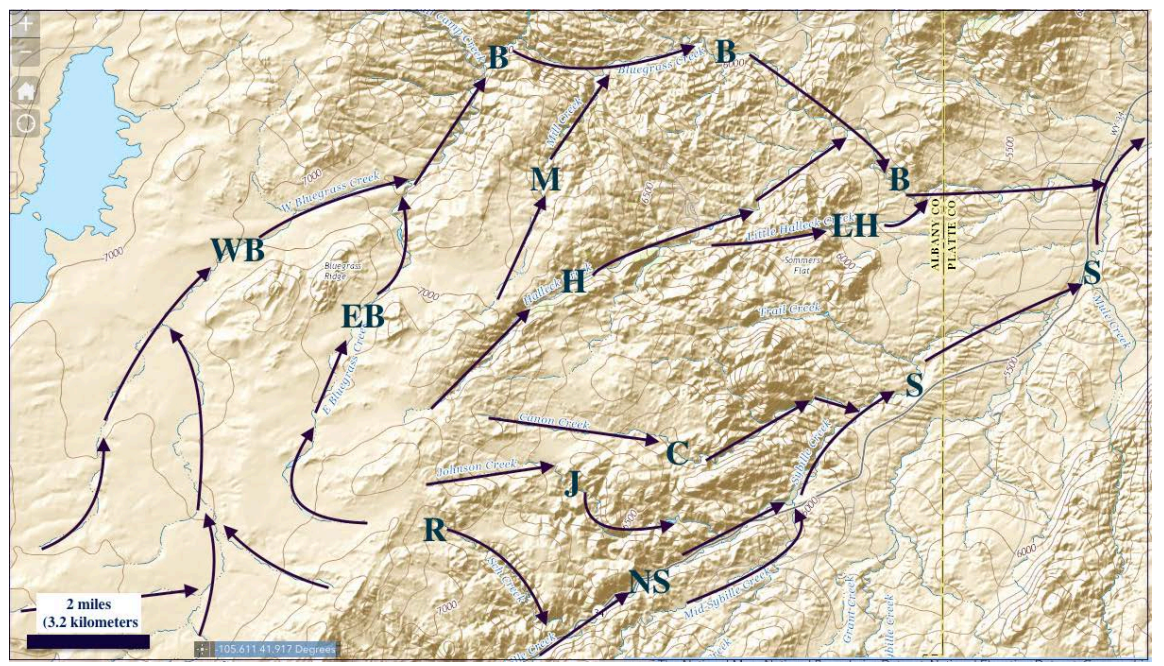

Figure 5. Modified map (contour interval 100 feet or 30.5 meters) from the USGS National Map Viewer website showing the Bluegrass Creek drainage system. Arrows emphasize drainage routes mentioned in text and show flow directions.

valleys. Letters identify drainage routes as follows: "B" Bluegrass Creek, "WB" West Bluegrass Creek, "EB" East Bluegrass Creek, "C" Canyon Creek, "H” Halleck Creek, "J" Johnson Creek, "LH" Little Halleck Creek, "M" Mill Creek, "R" School Creek, "S" Sybille Creek, and "NS" North Sybille Creek. The lake is the reservoir seen in Figure 3 and the north oriented Laramie River is located just to the west of Figure 5 (see Figure 3). Note how West Bluegrass Creek (and also East Bluegrass Creek) originate in what is today a narrow Laramie Basin floor area located between the north-oriented Laramie River and the Laramie Range western flank. The Laramie River exits the lake at a spillway (just west of Figure 5) with an elevation of 6964 feet (2123 meters) and the lowest point on the drainage divide between the Laramie River and West Bluegrass Creek has an elevation of about 7025 feet (2141 meters). Water almost certainly diverged from the Laramie River to enter the Bluegrass Creek drainage basin and to erode the West Bluegrass Creek valley before headward erosion of a slightly deeper northoriented Laramie River valley ended the flow and created the Laramie River-Bluegrass Creek drainage divide.

Large volumes of water must have also diverged from the Laramie River to erode the other diverging valleys seen in Figure 5. The drainage divide between the East and West Bluegrass Creek headwaters valleys has an elevation of less than 7200 feet (2195 meters) or approximately 200 feet (61 meters) higher than the Laramie River spillway elevation. A through valley with a floor elevation of less than 7160 feet (2182 meters), or less than 200 feet (61 meters) above the Laramie River spillway elevation, links the East Bluegrass Creek valley with the Halleck Creek headwaters valley. Once in the Laramie Range a 300-foot (91 meter) deep through valley with a floor elevation of less than 6960 feet (2121 meters) links the East Bluegrass Creek valley with the Mill Creek valley. Further south the East Bluegrass Creek drainage divide with the Johnson and School 
Creek headwaters has an elevation of between 7260 and 7280 feet (2213 and 2219 meters) or approximately 300 feet (91 meters) higher than the Laramie River spillway elevation. Massive volumes of water must have flowed from the Laramie Basin into these diverging bedrock-walled valleys that once in the Laramie Range converged in the Sybille Creek valley (which east of the Laramie Range converges with the Laramie River valley). Further south still other southeast-oriented North Sybille Creek tributary valleys originate along the Laramie Basin's eastern edge and have similar floor elevations.

Also note how the Laramie Range barely rises above the Laramie Basin floor and how the north oriented Bluegrass Creek tributary valleys and other east and southeast oriented Sybille Creek tributaries originate in the narrow zone between the north oriented West Bluegrass Creek headwaters and the Laramie Range west flank. Unlike Laramie Range areas surrounding the North Laramie River, Duck Creek, and Laramie River valleys Laramie Range crest areas between the Bluegrass Creek and North Sybille Creek valleys are not much higher than the Laramie Basin floor and decrease in an eastward direction. The extremely low Laramie Range elevations in the Figure 5 map area and the closely spaced network of diverging and converging bedrock-walled valleys are evidence that enormous volumes of water flowed from the Laramie Basin into the Laramie Range and then to the northeast-oriented Sybille Creek valley, which was being actively eroded by water that also diverged from the north oriented Laramie River (south of Figure 5). While today Sybille Creek flows in a northeast direction it may have originated as a southwest oriented valley prior to being beheaded and reversed by Bluegrass Creek (and also Laramie River) valley headward erosion. Southeast oriented flow from the Laramie Basin prior to the flow reversal may have eroded the southeast oriented School Creek valley.

\subsection{North Sybille/Sybille Creek Bedrock-Walled Valley}

Today the southernmost of the streams crossing from the Laramie Basin to the Great Plains is northeast oriented North Sybille/Sybille Creek and Wyoming state highway 14 uses its valley to cross the Laramie Range. North Sybille Creek originates in the Laramie Range and flows in a northwest direction to the Laramie Basin eastern edge (south of Figure 5) where it flows for a short distance in a north direction before turning in a northeast direction to again enter the Laramie Range (northwest oriented North Sybille Creek headwaters are also known as Plumbago Creek). In the Laramie Basin lowest points on the North Sybille Creek-Laramie River drainage divide are less than 7200 feet (2195 meters), which suggests water once diverged from the Laramie River to flow in a northeast direction through what is now the northeast-oriented North Sybille Creek/Sybille Creek canyon before converging with the Laramie River once the two different streams reached the Great Plains. Again in the Laramie Basin headward erosion of a slightly deeper north oriented Laramie River valley captured flow that had been diverging from the Laramie River into the northeast 
oriented North Sybille/Sybille Creek valley. Interestingly the north oriented North Sybille Creek segment flows on a Laramie Basin surface slightly lower than the north oriented Bluegrass Creek headwaters to the north.

Blackstone [15] describes a "discontinuous but extensive boulder-capped surface" in the region west of the Laramie Range and south of the reservoir seen in Figure 3 and Figure 5. He states most of the material is cobble in size although boulders up to 9 meters ( 30 feet) in maximum dimension have been found. The alluvium includes clasts of anorthosite indicating a Laramie Range source. $\mathrm{He}$ considers the alluvium to be of questionable Pleistocene age, although he adds, "The evidence is tenuous and is based on the character of the boulders, relation to source, elevation, and the local geomorphic history." The region referred to is located west of where North Sybille Creek flows on the Laramie Basin floor. While there is no reason to question a Laramie Range source present day drainage routes did not transport the coarse grained alluvium. Today almost all drainage in the region flows into the Laramie Range and not from the Laramie Range. Further Laramie Range elevations east of the "boulder-capped" surface area are today not much higher than the Laramie Basin floor. The cobbles and boulders were transported under very different conditions than exist today.

\subsection{Goshen Hole Relationship to the Bedrock-Walled Valleys}

Figure 6 illustrates the large escarpment-surrounded Goshen Hole lowland west end and its position related to where streams now crossing the Laramie Range converge. Letters identify drainage routes as follows: Bear Creek (“B”), Chugwater Creek (“C”), Dry Laramie River (“DL”), Horse Creek (“H”), Laramie River (“L”), North Laramie River (“NL”), North Platte River (“NP”), and Sybille Creek ("S"). A look a Figure 6 demonstrates the escarpment-surrounded Goshen Hole basin is directly to the east of where many of the bedrock-walled valleys converge.

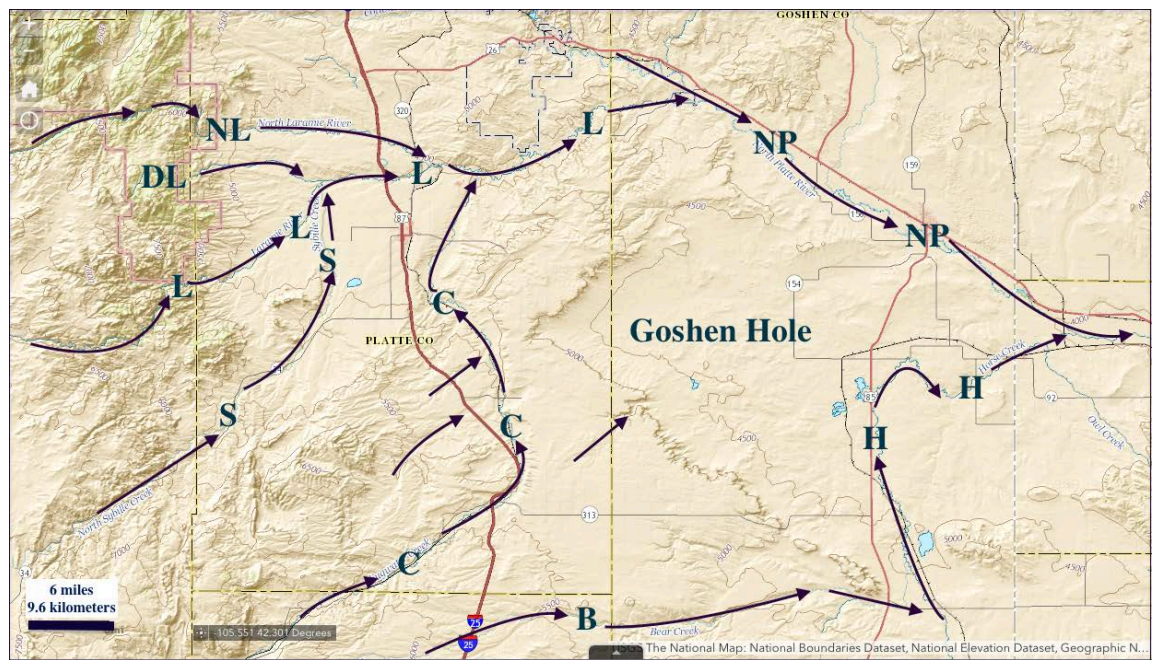

Figure 6. Modified map from USGS National Map Viewer website showing Goshen Hole position related to converging Laramie River tributaries Arrows emphasize drainage routes and flow directions and letters identify drainage routes as described in the text. 
The North Laramie River, Dry Laramie River, Laramie River, and Sybille Creek all converge just to the west of the Goshen Hole basin and just to the west of Figure 6 Bluegrass Creek joins Sybille Creek and Duck Creek joins the Laramie River. The convergence of these bedrock-walled valleys just to the west the Goshen Hole escarpment-surrounded basin suggests large volumes of east oriented water moved from the Laramie Basin across the Laramie Range to erode the Goshen Hole basin. However, today the Laramie River turns in a northeast direction to reach the southeast-oriented North Platte River and the north-oriented Sybille Creek and Chugwater Creek valleys are located between the northeast-oriented Laramie River valley and the Goshen Hole escarpment-surrounded basin. Further no topographic evidence suggests one or more dry valleys leads from the Laramie River valley to the V-shaped Goshen Hole escarpmentsurrounded basin.

Similar large escarpment-surrounded basins are scattered across the Great Plains and Rocky Mountain region. Typically these unique landforms appear to have formed as headcuts at the heads of deep stream eroded valleys, but today no stream flows to the valley heads and cross valleys now block routes streams flowing to the valley heads would have to have used. For this reason such escarpment-surrounded basins are often attributed to spring sapping and seepage weathering. While spring sapping and seepage weathering may be taking place today those processes do not explain the basin shapes or basin sizes nor do they explain the presence of cross valleys, like the Chugwater Creek valley, that are located directly "upstream" from the direction the basin opens. The similarity of these Great Plains and Rocky Mountain escarpment-surrounded basins and "upstream" cross valleys suggests similar processes may have formed all such escarpment-surrounded basins.

Three recent papers discuss how large southeast-oriented ice-marginal melt water floods actively eroded large headcuts in northwest or west directions until deep north- or northeast-oriented valleys eroded headward across the flood flow so as to leave four abandoned headcuts. The most recent paper [18] identifies a western North Dakota escarpment-surrounded basin at the west end of the east-oriented Knife River drainage basin and the west end of the north-facing Russian Springs Escarpment, which became an abandoned headcut when headward erosion of the deep north-oriented Little Missouri River valley captured massive east-oriented flood flow. Another paper [19] describes how massive southeast-oriented floods eroded the Jump-off escarpment-surrounded basin in northwest South Dakota around what is today the South Fork Grand River headwaters valley before being abandoned when headward erosion of the north-oriented Little Missouri River valley captured the southeast-oriented flow. The third paper [20] describes how the Sage Creek and Scenic Basins, which are located on the South Dakota plains to the east of the Black Hills, were left as large abandoned headcuts after headward erosion of the northeast-oriented Cheyenne River valley captured large southeast-oriented floods. The large Go- 
shen Hole escarpment-surrounded basin is similar to each of these other escarpment-surrounded basins.

The Goshen Hole basin location, the anastomosing bedrock-walled valley complex, the V-shaped Goshen Hole basin western end, and the similarity of the Goshen Hole escarpment-surrounded basin to other recently described and flood eroded escarpment-surrounded basins all strongly suggest immense volumes of water flowed from the Laramie Basin across the Laramie Range to erode the Goshen Hole basin as a large headcut. The headcut was eroded headward (or in a west direction) from a deep and actively eroding North Platte River valley. If so the north-oriented Sybille and Chugwater Creek valleys, which are now between the diverging and converging valley complex and the Goshen Hole basin, must have eroded headward to capture the east-oriented flow and to leave the Goshen Hole basin as an abandoned headcut. Several bedrock-walled valleys lead from the Laramie Basin to the Sybille Creek valley and it is not difficult to explain how Sybille Creek valley headward erosion captured the east-oriented flow that had been eroding the Goshen Hole Basin. The lack of abandoned valleys leading from the Sybille Creek valley to the Chugwater Creek valley and then to the Goshen Hole basin suggests the east-oriented flow probably was moving as large sheets of water.

\section{Discussion}

The multiple streams now flowing across the Laramie Range, the diverging and converging bedrock-walled valley complex, the Goshen Hole escarpment-surrounded basin location directly to the east and downstream of the anastomosing valley complex, and the similarity of the Goshen Hole basin to other large abandoned headcuts now found in western North and South Dakota, all suggest massive and prolonged floods of water once flowed from the Laramie Basin across the Laramie Range to reach the Great Plains and the southeast-oriented North Platte River valley. However, unlike the Washington State Channeled Scabland area, there is no evidence a large lake ever existed in the upstream Laramie River drainage basin, much less that such a lake catastrophically drained. Alpine glaciation has been reported in the Laramie River headwaters area [21] and in the Medicine Bow River headwaters area [22], but volumes of water contained in those small alpine glaciers, even with rapid melting, could not have produced the large and prolonged floods required to erode the landforms this paper describes.

Further complicating the picture is headward erosion of the east-oriented diverging and converging valley complex now crossing the Laramie Range appears to have captured multiple streams of south or southwest-oriented water that most likely came from somewhere to the north of the Laramie Range, yet today all possible source areas to the north have much lower elevations than the Laramie Basin floor, which is lower in elevation than Laramie Range areas the southor southwest-oriented water would have had to have crossed. Also evidence pre- 
sented here can be best explained if large volumes of water flowed in a south direction along the Laramie Basin floor before being reversed to create the present day north-oriented Laramie River drainage route. In other words evidence presented here is best explained if the massive and prolonged floods that crossed the Laramie Range first came from the north and later reversed their flow direction and came from the south, neither of which makes much sense based on today's topography.

One way to solve the massive and prolonged floodwater source is to consider White's [23] [24] "deep erosion by continental ice sheets" hypothesis. White argued that commonly accepted North American continental ice sheet histories do not adequately account for continental ice sheet erosion and those histories include the preservation of pre-glacial valleys and sediments in easily eroded bedrock, which according to White defies common sense logic. White's "deep erosion by continental ice sheets" hypothesis was strongly criticized [25] [26] with two major arguments being 1) thin mid and late Tertiary surficial sedimentary deposits demonstrate the ice sheets did not deeply erode the northern Great Plains; and 2) glacially deposited debris fills pre-glacial valleys north and east of the Montana, North Dakota, and South Dakota Missouri River valley and is evidence those valleys were components of a pre-glacial north-oriented drainage system often referred to as the pre-glacial Bell River system (see [27] [28] for Bell River system maps).

While few geologists since White's papers have challenged the Bell River pre-glacial age one recent (and previously cited [18]) paper demonstrates some Bell River valleys do not predate continental glaciation. That paper briefly suggests a large North American ice sheet created and occupied a deep "hole" and further explains how space in that "hole" was opened up as the ice sheet melted, which enabled the Bell River system of valleys to erode headward in sequence across immense southeast-oriented ice marginal melt water floods. That paper only addresses western North and South Dakota evidence, although it implies present day central and eastern Montana and northern Wyoming river valleys, including the Powder River valley, eroded headward across massive and prolonged southeast oriented ice marginal melt water floods. Powder River headwaters are located in central Wyoming and almost adjacent to a North Platte River tributary with a low drainage divide now separating the Powder and North Platte River drainage basins (see northwest corner of Figure 1). It is possible the massive melt water floods that eroded the Powder River drainage basin also reached this paper's southeast Wyoming study region.

A properly tweaked "deep erosion by continental ice sheets" hypothesis may be able to explain how melt water floods reached the high altitude Laramie Basin and crossed the even higher Laramie Range. The "hole" in which the continental ice sheet was located may not have been just created by deep ice sheet erosion, but also by crustal warping. If so, mountain ranges and plateau areas may have been uplifted as massive and prolonged melt water floods flowed across them. 
Two recently published papers and a paper to be published in early 2018 provide evidence massive southeast-oriented floods of what was probably continental ice sheet melt water did flow across emerging mountain ranges. The first paper describes how massive south-oriented floods eroded mountain passes now crossing segments of North America's east-west continental divide in the Beaverhead and Anaconda Mountain ranges that now surround the southwest Montana Beaverhead and Big Hole River drainage basins [29]. The second paper describes how massive south-oriented floods eroded mountain passes along the North American east-west continental divide and other drainage divides that now surround the Jefferson County, Montana, Boulder River drainage basin [30]. The third paper [31] provides evidence the South Dakota Black Hills emerged as massive southeast-oriented floods flowed across them. In other words it is possible the Laramie Range and the Rocky Mountain region began to be uplifted as massive and prolonged melt water floods flowed across and eroded them.

\section{Conclusions}

Topographic map evidence presented here makes a strong case that immense volumes of east-oriented water flowing from the Laramie Basin to the Great Plains intensely eroded Laramie Range areas the Laramie River and its tributaries now drain and also eroded the "downstream" Goshen Hole escarpment-surrounded basin. However based on commonly accepted geologic histories no recognizable water source exists. Landforms illustrated and discussed in this paper exist and must be explained even if that explanation requires reconsideration of commonly accepted geologic histories and of the previously rejected "deep erosion by continental ice sheets" hypothesis. Published interpretations of detailed topographic map evidence from additional Missouri River drainage basin areas is needed to better understand where the floodwaters that crossed the Laramie Range came from and also where those floodwaters went.

The "deep erosion by continental ice sheets" hypothesis if tweaked to include significant ice sheet related crustal warping of non-glaciated continental regions explains all topographic features discussed here. However, the "deep erosion by continental ice sheets" hypothesis requires the Bell River valley system to have been eroded when a large continental ice sheet melted, not prior to that ice sheet's formation, which may mean some or all Rocky Mountain and Great Plains mid and late Tertiary sediments do not predate North American continental glaciation as commonly accepted geologic histories claim. Too often erosional landform evidence has been ignored while other types of geologic evidence have been used to construct what are now commonly accepted geologic histories. Erosional landforms when properly interpreted tell a powerful and important story that does not always correlate with commonly accepted geologic histories. Much additional work is needed so geologists now working with other types of evidence will fully recognize erosional landforms as significant evidence that cannot be ignored. 


\section{References}

[1] Bretz, J.H. (1927) Channeled Scabland and the Spokane Flood. Washington Academy of Science Journal, 17, 200-211.

[2] Baker, V.R. (1981) Large-Scale Erosional and Depositional Features of the Channel Scabland. In: Baker, V.R., Ed., Catastrophic Flooding. The Origin of the Channeled Scabland, Dowden, Hutchinson and Ross, Inc., Stroudsburg, 276-310.

[3] Kehew, W.E. (1982) Catastrophic Flood Hypothesis for the Origin of the Souris Spillway, Saskatchewan and North Dakota. Geological Society of America Bulletin, 93, 1051-1058. https://doi.org/10.1130/0016-7606(1982)93<1051:CFHFTO>2.0.CO;2

[4] United Stated States Geological Survey (USGS) National Map Website. https://nationalmap.gov/small_scale/printable/reference.html\#list

[5] Thornbury, W.D. (1965) Regional Geomorphology of the United States. John Wiley and Sons, New York, 609 p.

[6] Frost, B.R., Frost, C.D., Chamberlain, K.R., Scoates, J.S. and Lindsley, D.H. (1996) A Field Guide to the Proterozoic Anorthositic, Monzontic, and Granitic Plutons, Laramie Range Southeastern Wyoming. Colorado Geological Survey Open-File Report 96-4 Field Trip No. 6, 29 p.

[7] Scoates, J. and Chamberlain, K.R. (2003) Geochronologic, Geochemical and Isotopic Constraints on the Origin of Monzonitic and Related Rocks in the Laramie Anorthosite Complex. Precambrian Research, 124, 269-304. https://doi.org/10.1016/S0301-9268(03)00089-5

[8] Mears Jr., B. (1991) Laramie Basin. In: Reheis, M.C., Palmquist, R.C., Agard, S.S., Jaworowski, C., Mears Jr., B., Madole, R.F., Nelson, A.R. and Osborn, G.D., Quaternary History of Some Southern and Central Rocky Mountain Basins. Chapter 14. In: Morrison, R.B., Ed., Quaternary Nonglacial Geology; Conterminous U.S., The Geology of North America, Vol. K-2. Geological Society of America, Boulder, CO, 418-427.

[9] McMillan, M.E., Angevine, C.L. and Heller, P.L. (2002) Postdepositional Tilt of the Miocene-Pliocene Ogallala Group on the Western Great Plains: Evidence of Late Cenozoic Uplift of the Rocky Mountains. Geology, 30, 63-66. https://doi.org/10.1130/0091-7613(2002)030<0063:PTOTMP >2.0.CO;2

[10] McMillan, M., Heller, P.L. and Wing, S.L. (2006) History and Causes of Post-Laramide Relief in the Rocky Mountain Orogenic Plateau. Geological Society of America Bulletin, 118, 393-405. https://doi.org/10.1130/B25712.1

[11] Adams, G.I. (1902) Geology and Water Resources of the Patrick and Goshen Hole Quadrangles in Eastern Wyoming and Western Nebraska. United States Geological Survey Water Supply and Irrigation Papers Number 70, 23-25.

[12] Higgins, C.G. (1990) Seepage-Induced Cliff Recession and Regional Denudation. In: Higgins, C.G. and Coates, D.B., Eds., Groundwater Geomorphology. The Role of Subsurface Water in Earth-Surface Processes and Landforms, Geological Society of America Special Paper 252, Boulder, 291-318.

[13] Rapp, J.R., Visher, F.N. and Littleton, R.T. (1957) Geology and Water Resources of Goshen County Wyoming. United States Geological Survey Water Supply Paper No. 1377, 17-18.

[14] United States Geological Survey (USGS) National Map Website. https://viewer.nationalmap.gov/advanced-viewer/

[15] Blackstone, D.L. (1975) Late Cretaceous and Cenozoic History of the Laramie Basin 
Region, Southwest Wyoming. In: Curtis, B.F., Ed., Cenozoic History of the Southern Rocky Mountains, Geological Society of America Memoir 144, 249-279. https://doi.org/10.1130/MEM144-p249

[16] Love, J.D., Christiensen, A.C. and Sever, C.K. (1980) Geologic Map of the Torrington 1 Degree x 2 Degree Quadrangle, Southeastern Wyoming. United States Geological Survey Miscellaneous Field Studies Map MF-1184.

[17] Oliver, D. (Unknown Date) History. Wheatland Irrigation District Website. http://widirrigation.com/Home/About

[18] Clausen, E. (2017) Using Map Interpretation Techniques for Relative Dating to Determine a Western North Dakota and South Dakota Drainage Basin Formation Sequence, Missouri River Drainage Basin, USA. Journal of Geography and Geology, 9 , 1-18. https://doi.org/10.5539/jgg.v9n4p1

[19] Clausen, E. (2017) Origin of Little Missouri River-South Fork Grand River and Nearby Drainage Divides in Harding County, South Dakota and Adjacent Eastern Montana, USA. Open Journal of Geology, 7, 1063-1077. https://doi.org/10.4236/ojg.2017.78071

[20] Clausen, E. (2017) Solving a Perplexing Scenic and Sage Creek Basin Drainage History Problem, Pennington County, South Dakota, USA. Journal of Geography and Geology, 9, 1-10. https://doi.org/10.5539/jgg.v9n2p1

[21] Kiver, E.P. (1972) Two Late Pinedale Advances in the Southern Medicine Bow Mountains, Colorado. Contributions to Geology, 11, 1-8.

[22] Oviatt, C.G. (1977) Glacial Geology of the Lake Marie Area, Medicine Bow Mountains. Rocky Mountain Geology, 16, 27-38.

[23] White, W.A. (1972) Deep Erosion by Continental Ice Sheets. Geological Society of America Bulletin, 81, 1037-1056. https://doi.org/10.1130/0016-7606(1972)83[1037:DEBCIS]2.0.CO;2

[24] White, W.A. (1988) More on Deep Glacial Erosion by Continental Ice Sheets and Their Tongues of Distributary Ice. Quaternary Research, 30, 137-150. https://doi.org/10.1016/0033-5894(88)90019-1

[25] Sugden, D.E. (1976) A Case against Deep Erosion of Shields by Ice Sheets. Geology, 4, 580-582. https://doi.org/10.1130/0091-7613(1976)4<580:ACADEO>2.0.CO;2

[26] Gravenor, C.P. (1975) Erosion by Continental Ice Sheets. American Journal of Science, 275, 594-604. https://doi.org/10.2475/ajs.275.5.594

[27] McMillan, J.N. (1973) Shelves of the Labrador Sea and Baffin Bay, Canada. Canadian Society of Petroleum Geologists Memoir, 1, 473-515.

[28] Sears, J.W. (2013) Late Oligocene-Early Miocene Grand Canyon: A Canadian Connection? GSA Today, 23, 4-10. https://doi.org/10.1130/GSATG178A.1

[29] Clausen, E. (2017) Origin of Mountain Passes across Continental Divide Segments Surrounding the Southwest Montana Big Hole and Beaverhead River Drainage Basins, USA. Open Journal of Geology, 7, 1362-1385. https://doi.org/10.4236/ojg.2017.79091

[30] Clausen, E. (2017) Analysis of Mountain Passes along the East-West Continental Divide and Other Drainage Divides Surrounding the Boulder River Drainage Basin, Jefferson County, Montana, USA. Open Journal of Geology, 7, 1603-1624. https://doi.org/10.4236/ojg.2017.711108

[31] Clausen, E. (2018) Topographic Map Analysis of High Elevation Black Hills through Valleys Linking Spearfish and Rapid Creek Headwaters Valleys, Lawrence County, South Dakota, USA. Journal of Geography and Geology, 10, 8-21. https://doi.org/10.5539/jgg.v10n1p8 